\title{
Strategies for measuring airway mucus and mucins
}

\author{
Kalina R. Atanasova and Leah R. Reznikov * (D)
}

\begin{abstract}
Mucus secretion and mucociliary transport are essential defense mechanisms of the airways. Deviations in mucus composition and secretion can impede mucociliary transport and elicit airway obstruction. As such, mucus abnormalities are hallmark features of many respiratory diseases, including asthma, cystic fibrosis and chronic obstructive pulmonary disease (COPD). Studying mucus composition and its physical properties has therefore been of significant interest both clinically and scientifically. Yet, measuring mucus production, output, composition and transport presents several challenges. Here we summarize and discuss the advantages and limitations of several techniques from five broadly characterized strategies used to measure mucus secretion, composition and mucociliary transport, with an emphasis on the gel-forming mucins. Further, we summarize advances in the field, as well as suggest potential areas of improvement moving forward.
\end{abstract}

Keywords: Airway mucus, Mucociliary transport, Techniques, Mucins

\section{Background}

Increased airway mucus and airway obstruction are hallmark features of many respiratory diseases [1-4]. The composition of mucus and its properties have long been considered informative for airway disease diagnosis and progression. However, studying mucus presents several challenges, including a complex and heterogeneous composition, limitations in collection methods, and laborious procedures for downstream processing. Although, advances in imaging techniques have improved aspects of mucus research, these techniques remain less accessible due to the expertise required and equipment necessary to execute. Here, we review and discuss the advantages and limitations of several techniques from four broadly characterized strategies used to measure mucus properties and mucociliary transport (MCT). The advantages and limitations of such techniques have rarely been discussed. Doing so has the potential to both impact and inform researchers and clinicians alike, which may ultimately influence patient treatment and care.

* Correspondence: leahreznikov@ufl.edu

Department of Physiological Sciences, University of Florida, 1333 Center Drive, PO Box 100144, Gainesville, FL 32610, USA

\section{Airway surface liquid (ASL) in health and disease}

Airway surface liquid (ASL) is the thin liquid film that covers the airways [5]. It protects the airways from desiccation and facilitates the swift removal of inhaled particulates, debris, pathogens and toxicants through mucociliary transport (MCT). From a structural standpoint, ASL consists of two main layers: 1) the apical layer consisting of a water-based polymeric mucus; and 2) a periciliary layer (PCL), also referred to as a sol layer, [6] that bathes the epithelium (Fig. 1). Historically, studies suggest that goblet cells, serous cells and submucosal glands contribute to ASL production [7-10]. The recent discovery of the airway ionocyte $[11,12]$ might also result in a revised understanding of ASL production.

Although the majority of ASL is water [13], large glycoproteins known as mucins [14] make up a significant portion of the proteins in the apical mucus layer. Mucins are encoded by different $m u c$ genes, after which the proteins are generally named and numbered in the order of discovery $[15,16]$. Currently there are $21 \mathrm{mu}$ cins identified in humans (denoted with capital letters), 13 of which are found in the respiratory tract $[7,16]$. They can be divided into three classes depending on their ability to polymerize, and on whether they are secreted or are cell surface-bound [7]. These three groups include the secreted monomeric mucins (MUC7,

(c) The Author(s). 2019 Open Access This article is distributed under the terms of the Creative Commons Attribution 4.0 International License (http://creativecommons.org/licenses/by/4.0/), which permits unrestricted use, distribution, and 


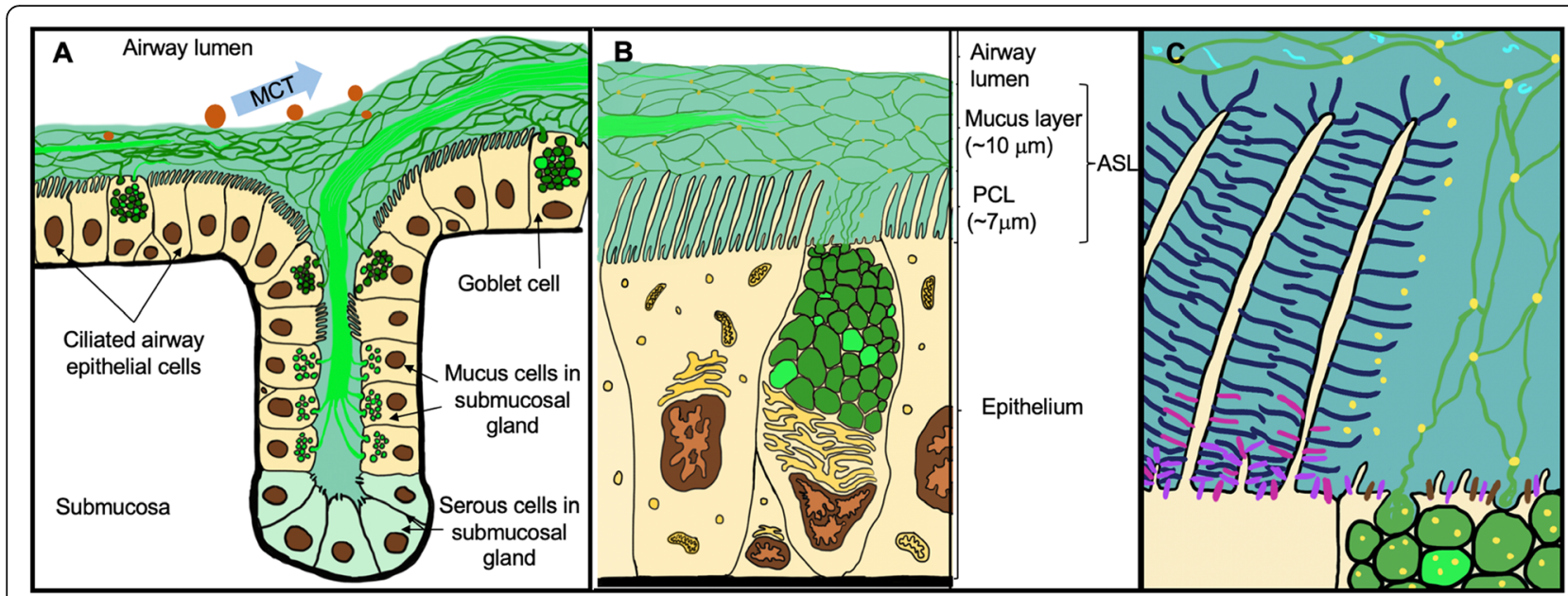

Fig. 1 Airway Surface Liquid (ASL) and Localization of the Major Mucins in Healthy Airways. a General schematic representation of mucus secretion from goblet cells and submucosal glands. The proposed structure of MUC5AC (threads in dark green) and MUC5B (bundles/strands in bright green) is shown. Mucociliary transport (MCT) of inhaled pathogens and particles (orange spheres of different sizes) is shown with a blue arrow. $\mathbf{b}$ Schematic representation of the generally-accepted structure of ASL. The periciliary layer (PCL) is estimated to be $\sim 7 \mu \mathrm{m}$ thick under normal conditions. Mucus layer thickness varies among individuals and in the different parts of the airway of the same individual (up to $70 \mu \mathrm{m}$ ) under normal conditions. c ASL gel-on-brush model with localization of large airway mucosal epithelium-expressed membrane-tethered mucins $(\mathrm{MUC1}=$ purple, $\mathrm{MUC4}=$ dark blue and $\mathrm{MUC13}=$ pink and $\mathrm{MUC16}=$ brown $)$ and their interactions with secreted gel-forming $(\mathrm{MUC5}$ AC = dark green, $\mathrm{MUC5B}$ = bright green) and monomeric mucins ( $M U C 7$ = light blue; only depicted as incorporated in the gel-layer). Globular, non-mucin proteins that are secreted by different cells and incorporated within the gel mesh are represented in yellow dots in b) and c). MUC8 and MUC19 are omitted due to the sparsity of data on their secretion and localization in normal respiratory tissues. The MUC2 gel-forming mucin has also been omitted in this figure due to the very low levels of expression and secretion in normal airways (see text for references). MUC20, MUC21 and MUC22 were also omitted

MUC8), the secreted polymeric (gel-forming) mucins (MUC2, MUC5AC, MUC5B and MUC19) and nonsecreted surface-bound mucins (MUC1, MUC4, MUC13, MUC16, MUC20, MUC21 and MUC22).

Deviations in the composition of ASL, and particularly the mucus layer, are associated with several airway diseases, including asthma, cystic fibrosis and COPD [1-4, 17]. These alterations can be due to enhanced mucin production and secretion, and/or a reduction in water content. For example, in asthma the enhanced production of MUC5AC due to goblet cell hyperplasia, paired with airway remodeling and inflammation, drive airway morbidity and mortality. Indeed, the Severe Asthma Research Program (funded by the NHLBI) found that $58 \%$ of people with asthma exhibited airway mucus plugs [1]. The extent of mucus plugging correlated with airflow limitation and worse control of asthma. Similarly, a recent study involving the AREST CF program found that airway mucus plugging was a significant predictive indicator of future lung function [4], and it is well known that people with cystic fibrosis undergoing lung transplantation exhibit profound mucus plugging of the small airways [2]. However, mucus abnormalities in cystic fibrosis are thought to be due to a combination of events, including ASL dehydration [8, 18], altered electrostatic interactions of mucins $[13,19]$, impaired mucus detachment [20], as well as changes in mucin content
[21]. Airway obstruction is also a common feature of COPD [22]. Recent SPIROMICS data suggested that sputum mucin concentrations, including MUC5AC and MUC5B [23], were markers of disease severity in COPD. Although the mechanisms mediating mucin alterations in COPD are still being elucidated, inflammation [24], smoking [25] and acquired ion channel dysfunction [26] are key contributors.

\section{Gel-forming mucins}

Mucins are heterogeneous glycoproteins [15, 27, 28]. The protein backbones have unique multiple amino-acid tandem repeats containing serines and threonines, where oligosaccharides are covalently linked. The backbones represent $\sim 20 \%$ of the molecular weight, whereas the carbohydrates account for $\sim 80 \%$ of the weight $[7,29]$. The carboxy and amino terminals of the backbones are rich in cysteine, allowing for end-to-end disulfide bonds and subsequent dimerization or multimerization. This multimerization results in a complex hydrated porous molecular network that, together with the other components secreted by airway epithelial cells and submucosal glands, represent the gel basis of airway mucus [27, 29, 30]. Indeed, once released via exocytosis, mucins can expand more than 100 times their dehydrated size [27, 29, 31]. This property is partly why mucins represent such a large portion of the proteins that make up the mucus 
layer. The structure, biosynthesis, glycosylation and secretion mechanisms of mucins have been extensively studied and reviewed elsewhere [3, 15, 29, 30, 32], and therefore will not be further addressed here.

MUC5AC and MUC5B represent the major secreted gel-forming mucins and are responsible for the viscoelastic and functional properties of mucus in health and disease [33]. Although MUC2 has been shown to be among the major gastro-intestinal mucins, and gestationally associated with airway developing cells [16, 34], it is expressed and secreted in very small quantities in "normal" airway tracheo-bronchial epithelia [35]. To date there is very little data on MUC19. Its expression in the respiratory system has been localized to submucosal glands [36, 37], but there is limited data to inform on its secretion properties [37].

In addition to mucins, inflammatory cells [38] and host defense proteins [39] are often found in mucus. There is significant diagnostic value in examining inflammatory cells and inflammation profiles. For example in asthma, tailoring treatments based upon presence of eosinophils [40] has been an effective strategy to decrease asthma exacerbations [41]. Neutrophils are also commonly found in airways of individuals with severe asthma [42] and cystic fibrosis [43]. A greater number of neutrophils in the lavage fluid of smokers, as well as the sputum of people with COPD, has also been reported $[44,45]$. Neutrophils modify mucus properties and increase mucus viscosity through releasing DNA nets [46, 47]. Thus, in instances where mucus is extremely viscous, agents that "thin" mucus, such as mucolytics, might be required for mucus processing [48]. Additional cells found in healthy and diseased lungs include macrophages and lymphocytes, among others [44].

\section{Challenges in measuring airway mucus and mucins}

Despite strong evidence that deviations in mucus abundance and/or composition drive mortality and morbidity in several airway diseases [1-4], measuring mucus and mucins remains a challenge $[49,50]$. For example, obtaining mucus in vivo from the trachea, bronchi and bronchioles can be difficult due to limitations in collection methods, as well as the potential for contamination with saliva. Further, accessing the trachea, bronchi, and lungs in humans and animal models to collect mucus is invasive and can be confounded by MCT.

In vitro measurements, on the other hand, might not be an accurate representation of the in vivo environment, as many of the neural, endocrine and immune systems, which regulate mucus secretion and mucin production, are lacking [51]. For example, mucus secretion and MCT are directly regulated by sympathetic and parasympathetic reflexes [52]. Endogenous sex hormones also play role in diseases such as asthma [53]. Additionally, the formation of mucus plugs that can lethally obstruct the airways are difficult to study in a cell culture system where the airway architecture, including luminal spaces, are missing $[1,54]$.

Although animal models are often used to study respiratory diseases, they show marked differences in their airway anatomy and structure, including abundance of submucosal glands [32, 51, 55, 56]. These anatomical and physiological differences can make extrapolation of research findings to humans difficult. Further, speciesdependent differences in the structure of gel forming mucins [57], including differences in amino-acid sequences [58] and sugar side-chains [59], make standard quantitative and semi-quantitative techniques that use antibodies (e.g., western blot, ELISA, etc.) more arduous.

Another challenge in the mucus biology field is the significant influence that environmental factors, such as infections, inflammation, and smoking, have on mucus properties. As mentioned previously, neutrophils increase mucus viscosity by extruding DNA material [46, 47]. Cigarette smoke, on the other hand, can increase the production of MUC5AC [60] and increase neutrophil number. Additionally, infection with Pseudomonas aeruginosa increases sialyation of mucins, which facilitates Pseudomonas aeruginosa colonization [61]. Combined, these factors can make sampling and downstream processing of mucus unpredictable and tedious. More extensive information related to environmental influences on mucus is provided by Fahy and Dickey [62].

Despite these challenges, several techniques have been developed to assess mucin expression and mucus content. Below we highlight some of these methodologies and comment on their advantages and limitations, with an emphasis on the gel-forming mucins. Though we focus on gel-forming mucins, many of the approaches discussed here are also applicable to studies centered on airway inflammation and inflammatory cells trapped in mucus.

\section{Techniques for measuring mucus and mucin}

The assessment of mucus can occur on many different levels, requiring many different strategies. Here we outline five broad categories and briefly highlight some common methodologies representative of each category. More detailed information regarding advantages and limitations of techniques discussed is provided in the corresponding tables.

\section{Collection methods (Fig. 2, Table 1)}

An ongoing challenge in the mucus biology field is the collection of samples. There are several strategies that can be implemented, each with distinct advantages and limitations. For airway epithelia grown at the air-liquid 


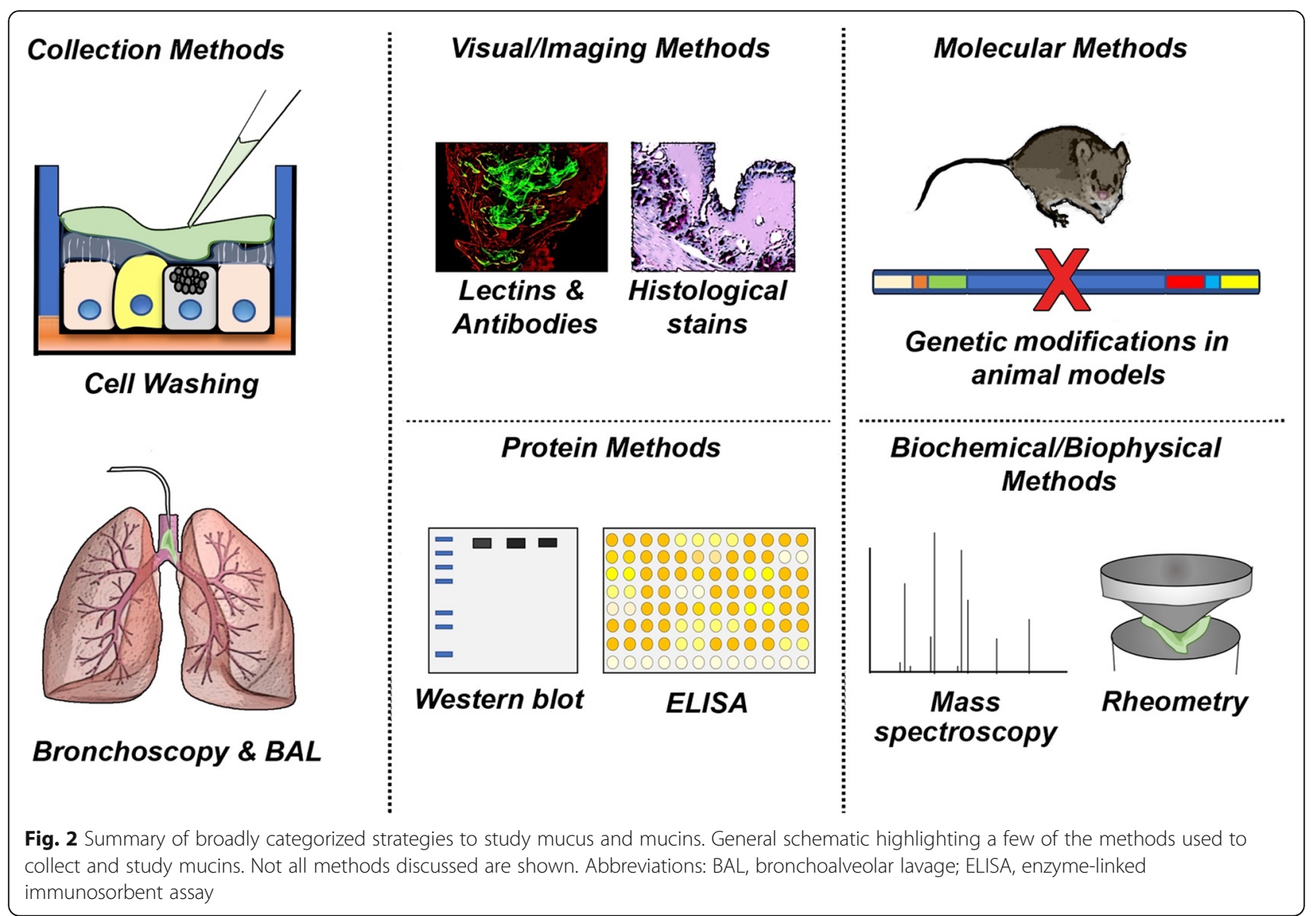

interface (ALI), a common practice is to perform an apical wash. This approach is fairly simple, and offers an advantage in that samples can be assayed in response to interventions [63, 64]. However standardized procedures need to be practiced, as accumulated mucins might not be removed properly without successive washing [65]. Further, pooling of samples might be required [66], which necessitates a greater sample size. Any studies in which ALI cultures are used to measure mucus secretion and its properties must account for experimental confounds, such as mechanical stimulation and/or unintentional goblet cell discharge [65].

Another collection approach similar to cell washing is bronchoalveolar lavage (BAL). This technique can be utilized both in vivo [67] or ex vivo [68] and entails the irrigation and retrieval of a known volume of fluid from a defined area of the airway tree. For humans, a BAL requires a bronchoscopy [81]. An advantage of BAL is that it can be utilized in human patients [69] and experimental model systems. However, important limitations are the need for general anesthesia [70], variation in retrieval volumes [71], and the impact that local inflammatory cells can have on the retrieval process (e.g., lung permeability [82]).
Sputum also provides information about mucus and mucins. This heterogeneous material consisting of cells and mucus is expelled from the lower airways via cough. There are two major types of sputum: induced and spontaneous. An advantage of spontaneous sputum is that no clinical intervention is required for its production. Conversely, induced sputum entails aerosolization of hypertonic saline $[74,75]$ to the airways using standardized protocols [73]. An advantage of induced sputum is that standardized protocols facilitate reproducibility and rigor across studies. Limitations of both spontaneous and induced sputum include the possibility for saliva contamination, as well as variations in the amount of sputum produced [76]. Further, the success of sputum induction is influenced by the degree of inflammation [72] and caution should be practiced when working with asthmatic patients (due to the bronchoconstriction effects of hypertonic saline [83]). Despite these limitations, sputum is widely used to study airway mucus and airway inflammation [84].

Bronchoscopy is also used to collect and study mucus. As highlighted previously, bronchoscopy is required to perform BAL. However, bronchoscopy can also be used to facilitate removal of mucus plugs [77]. In some cases, 
Table 1 Advantages and limitations of mucus and mucin collection methods

\begin{tabular}{|c|c|c|}
\hline Method & Advantages & Limitations \\
\hline Cell culture wash & $\begin{array}{l}\text { - Requires minimal specialized equipment } \\
\text { and is not overly tedious. } \\
\text { - Can sample mucus in response to } \\
\text { interventions }[63,64] \text {. } \\
\text { - Potential for repeated collection and/ } \\
\text { or longitudinal study. }\end{array}$ & $\begin{array}{l}\text { - Accumulated mucins might not be removed properly } \\
\text { if washing is not done successively or is incomplete [65]. } \\
\text { - Samples may require pooling [66]. }\end{array}$ \\
\hline $\begin{array}{l}\text { Bronchoalveolar } \\
\text { lavage }\end{array}$ & $\begin{array}{l}\text { - Allows for direct sampling of the airway } \\
\text { fluid } \\
\text { - Applicable in vivo [67] and ex vivo [68]. } \\
\text { - Relatively large volumes can be } \\
\text { retrieved. } \\
\text { - Materials to perform are standard. } \\
\text { - Can be performed in human patients [69]. } \\
\text { - Potential for repeated and/or longitudinal } \\
\text { sampling. }\end{array}$ & $\begin{array}{l}\text { - Must be clinically indicated in order to perform in } \\
\text { humans. } \\
\text { - Generally done under local anesthesia in vivo [70]. } \\
\text { - Fluid retrieved is a combination of multiple cells and } \\
\text { multiple proteins [67]. } \\
\text { - Volume recovered is variable [71]. } \\
\text { - Non-adherent proteins may be overrepresented }\end{array}$ \\
\hline $\begin{array}{l}\text { Sputum (spontaneous } \\
\text { and induced) }\end{array}$ & $\begin{array}{l}\text { - Provides information about mucus and } \\
\text { mucins in the lower airways } \\
\text { - Spontaneous sputum requires no } \\
\text { intervention for its production } \\
\text { - Induced sputum provides a higher } \\
\text { proportion of viable cells [72]. } \\
\text { - Guidelines in place for inducing sputum } \\
\text { in human [73]. }\end{array}$ & $\begin{array}{l}\text { - Potential for contaminated with saliva. } \\
\text { - Induced sputum usually requires inhalation of } \\
\text { hypertonic saline, which can be irritating and change } \\
\text { composition of mucus [74, 75]. } \\
\text { - Success of sputum induction influenced by inflammation [72]. } \\
\text { - Variations in the amount of sputum produced [76]. } \\
\text { - Not really applicable to animal models. }\end{array}$ \\
\hline Bronchoscopy & $\begin{array}{l}\text { - Direct sampling of mucus when used to } \\
\text { remove plugs [77]. } \\
\text { - Provides significant diagnostic } \\
\text { information. } \\
\text { - Can be performed in human and animal } \\
\text { patients. }\end{array}$ & $\begin{array}{l}\text { - Performance in human patients or animal patients requires } \\
\text { highly specialized equipment and training } \\
\text { - Typically performed under conscious sedation, occasionally } \\
\text { occur under general anesthesia [70]. }\end{array}$ \\
\hline $\begin{array}{l}\text { Endotracheal tube } \\
\text { sampling }\end{array}$ & - Direct sampling of mucus $[78,79]$. & $\begin{array}{l}\text { - Hydration of the mucus varies from the inside or the outside } \\
\text { of the tube [80] } \\
\text { - Endotracheal tube placement in human and animal patients } \\
\text { requires highly specialized training and a licensed medical } \\
\text { practitioner. }\end{array}$ \\
\hline
\end{tabular}

removal of a mucus plug may necessitate the application of mucolytics [77]. A significant advantage of bronchoscopy is the diagnostic information it provides, as well as the ability to directly sample mucus. Potential limitations (as highlighted above) include the need for general anesthesia and requirement for a licensed medical practitioner to perform.

Lastly, mucus may be collected from endotracheal tubes $[78,79]$. Endotracheal tubes are generally placed under two circumstances: critical illness and general anesthesia (for airway management) [85]. Mucus often accumulates in the endotracheal tube [78], and in some cases, creates a plug [86]. Upon extubation, the mucus material can be directly collected and studied from either inside or outside of the tube. An advantage of endotracheal tube mucus sampling is that it is a direct interrogation of airway mucus. However, a limitation of endotracheal tube sampling is that the hydration of the mucus varies from the inside or the outside of the tube [80] which can decrease reproducibility across experiments. Similar to bronchoscopy, endotracheal tube placement in humans requires a licensed medical practitioner.

\section{Visual and imaging methods (Fig. 2, Table 2)}

Several methods, including histological stains (e.g., Alcian Blue (AB), Periodic Acid-Schiff (PAS)), lectins and antibodies remain the most basic and ubiquitously used visual techniques to examine mucus and mucins $[90,92,93,100$, 101]. These methods offer the advantage in that they are relatively simple to perform. They also offer spatial context, as procedures are typically performed on airway tissue sections. Antibodies offer greater specificity and direct detection of mucins, whereas $\mathrm{AB} / \mathrm{PAS}$ and lectins are indirect. Important considerations for quantification of histological, lectin and antibody-based methods include maintaining the same fixation $[102,103]$ and imaging parameters (e.g., lamp or laser intensity, magnification) across samples, imaging a sufficient number of fields to acquire accurate representation of the sample, and ensuring that the samples are acquired from the same anatomical location across subjects [104]. In many cases, collaboration with a pathologist facilitates proper analysis. Additional considerations and recommendations are highlighted elsewhere $[105,106]$.

Mucus thickness, viscoelasticity, and transport properties can be examined in vitro and ex vivo using 
Table 2 Advantages and limitations of visual and imaging methods and techniques used for measuring mucus properties

\begin{tabular}{ll}
\hline Method & Advantages \\
\hline $\begin{array}{l}\text { Beads/microspheres visualization } \\
\text { and tracking in vitro [87-89], }\end{array}$ & - Easily visualized. \\
ex vivo [20,90] and in vivo [91] & \\
& \\
& \\
Histology \& Immunostaining & - Inexpensive, easily visualized. \\
(using specific antibodies, Lectins, & - Specific antibodies can provide precise \\
PAS/AB) [90, 92, 93] & mucin detection and localization or co- \\
& localization with other molecules. \\
& - Fluorescent lectins can be used for semi- \\
& quantitation by fluorescence intensity \\
& measurement and are inexpensive
\end{tabular}

Electron microscopy [94] - In depth view of micro anatomical structures of cells and gel-forming mucins.

\section{$\mathrm{X}$-ray imaging analysis} $[1,20,95-98]$

Volumetric - submucosal gland bubble visualization $[55,99]$
- Novel techniques provide in vivo ability to detect mucus

- Very recent X-ray synchrotron [96] and quazimonochromatic $X$-ray phase-contrast imaging techniques have been applied successfully to measure MCT in vivo, together with lung motion.

- Can detect mucus plugs in humans in vivo.

- Detect ex vivo/in vitro increased output from single cell or multiple glands under normal or treatment conditions.

- The total volume technique gives a simple quantitation of total mucus secretion ex vivo/in vitro for a constant time period at baseline and/ or after treatment.

Limitations

- Most applicable in vitro and in small animal models ex vivo/in situ.

- Data analysis can require careful application of modelled calculations that present opportunities for error.

- Some of the in vivo applications may require expensive visualization set up.

- Applicable mostly in vitro and ex vivo.

- When scoring systems are utilized, careful analysis by multiple individuals blinded to group treatments are necessary.

- Fixation and washing steps might result in mucus being washed away.

- Lectins bind to different carbohydrates in the oligosaccharide chains of glycoproteins and glycolipids and therefore are not mucin specific.

- Difficult to detect more than one type of gel mucin at the same time.

- The type and duration of fixation is very important for retention of mucin structures.

- Expensive set-up and materials.

- Potential for exposure to harmful rays.

- At the moment, are limited in utility for longitudinal in vivo studies.

- Highly specialized equipment and skills

- Volume output may not necessarily comprise only mucus but can also include changes in serous glandand non-glandular cell-secretions.

- Currently not applicable in vivo. microscopy with fluorescent probes and dyes that label or diffuse through mucus [20, 87, 88, 91, 95, 107]. Imaging as a tool to measure viscoelastic properties is covered in greater detail in a subsequent section. Experiments in which fluorescent probes and particles are used to assess mucus require careful consideration, as factors such as $\mathrm{pH}$ sensitivity, photostability, brightness, and size influence experimental design and outcome. However, an advantage of using fluorescent probes, particles, and dyes is that they offer spatial and temporal resolution when visualized by a microscope. This can be beneficial for investigating experimental or therapeutic interventions, as well as delineation of the layers of ASL impacted by an intervention or disease. Further, these techniques can be used in multiple species, making comparative studies possible. Finally, because these methods are used quite extensively, they are generally wellaccepted. However, one limitation is the lack of specificity for studying mucin (e.g., assessing mucus and ASL, not mucin directly). Additionally, because many experiments using fluorescent probes and particles occur in vitro or ex vivo, careful control of environmental conditions, which may necessitate environmental chambers, is needed to minimize the introduction of unintentional artifacts and confounds.

Several imaging techniques have been pioneered over the years that allow for examination of mucus (and ciliary) function in vivo through assessment of MCT. Currently, in humans, measuring MCT in the conducting airways of the lung has been chiefly accomplished through radioactive aerosols [108]. These studies can be laborious and time-consuming and require highly specialized and standardized testing environments/equipment. Further, initial deposition of radioactive aerosols, which is impacted by particle size and breathing, greatly influence the rate by which mucus is cleared [108]. This can create "noise" and increase the sample number required to detect differences within and across human populations.

In animal models, fluorescent or radiopaque particles have been used to measure MCT in vivo and ex vivo. Advanced imaging modalities are often required to conduct these experiments, and the post-hoc analysis can be quite extensive and demanding, depending upon the 
method used. However, these techniques offer a greater resolution and granularity compared to MCT studies conducted in humans that use radioactive aerosols [20]. They also allow for the impact of interventions on MCT to be assessed in vivo. Additional assays to visualize mucus and mucins include volumetric determination of submucosal gland secretions using an oil interface [55, 99] and electron microscopy [94]. Newer techniques that visualize mucus flow and MCT by scintigraphy [109] and X-ray imaging techniques $[1,20,96-98]$ have also been employed. In some cases, these newer techniques allow for the detection of mucus plugs in humans [1].

\section{Molecular and genetic approaches (Fig. 2, Table 3)}

Traditional molecular tools, including quantitative RTPCR, Northern blot and in situ hybridization, allow for examination of mucin expression at the RNA level [110-112, 116]. These methods are relatively popular due to their low cost, high specificity, and quantitative nature. A limitation of these types of approaches is that mRNA expression may not reflect protein levels. Further, no direct information regarding mucus/mucin secretion and/or mucus composition is provided. Luciferase reporter assays and ChIP assays can also allow for examination of pathways involved in mucin gene regulation $[111,113]$. More recently, newer technologies, including single RNA-sequencing [12], have provided new information regarding mucin expression and properties of mucus-secreting cells. We expect that expanded use of this technology will continue to enhance our knowledge of mucus and mucins in both health and disease.

Major breakthroughs in the field of mucus biology occurred when genetically-modified rodent models that overexpressed or lacked specific mucins were generated $[89,114,115]$. Muc5B knockout mice have shown the importance of muc5B in MCT and inflammatory cell responses (e.g., phagocytosis and apoptotic cell clearance), whereas muc5AC knockout models did not show any significant MCT deficiencies [114]. However, muc5AC knockout mice had a $74 \%$ reduction in airway obstruction when challenged with antigens to mimic allergic asthma. These results were observed without a dampening of inflammatory responses [115], suggesting that muc5AC was the major contributor to inflammationinduced airway obstruction. Muc5AC overexpressing animals, on the other hand, have been instrumental in showing the importance of muc5 $\mathrm{AC}$ in the protection of the airways against viral invasions [89]. Specifically, an approximately 18 -fold increase in muc5AC expression did not alter MCT, but instead protected the animals from aerosolized influenza challenge [89]. Thus, these animal models have provided unique insight into the specific roles of muc5AC and muc5B in airway health and disease. They also provide a unique advantage in that mucin biology and function can be studied with all the critical in vivo regulatory systems intact. Given species differences in airway structure and physiology, extrapolations from rodents to humans still requires caution. As such, additional comparative studies using other species might be beneficial.

\section{Quantitative and semi-quantitative protein detection of mucus and mucin (Fig. 2, Table 4)}

Standard protein techniques, such as ELISA $[117,118]$ and antibody detection-based western blotting [100, $119]$, are frequently used to study mucus and mucins.

Table 3 Advantages and limitations of molecular and genetic methods and techniques used in mucus research

\begin{tabular}{|c|c|c|}
\hline Method & Advantages & Limitations \\
\hline $\begin{array}{l}\text { Quantitative RT-PCR } \\
\text { [110-112] }\end{array}$ & $\begin{array}{l}\text { - Very specific quantitative information on mucin } \\
\text { expression at the mRNA level } \\
\text { - Inexpensive and easily applicable to most samples. }\end{array}$ & $\begin{array}{l}\text { - Inability to detect increase in secretion. } \\
\text { - Post-transcriptional modifications are also } \\
\text { not detected. }\end{array}$ \\
\hline $\begin{array}{l}\text { Northern-blot (RNA-blot) } \\
\text { assay }[110,111]\end{array}$ & $\begin{array}{l}\text { - Alternative method for detection of RNA. } \\
\text { - Allows for separation of RNA molecules by size. } \\
\text { - Provides information on number, length, and } \\
\text { relative abundance of mRNAs expressed by a single } \\
\text { gene }\end{array}$ & $\begin{array}{l}\text { - More laborious, time-consuming and not } \\
\text { as sensitive as qRT-PCR. } \\
\text { - Requires large amount of tissue/sample, and } \\
\text { high purity and quality of non-degraded RNA, } \\
\text { which can be difficult for the large RNA } \\
\text { molecules of mucins. }\end{array}$ \\
\hline $\begin{array}{l}\text { Luciferase reporter and Chromatin } \\
\text { immunoprecipitation (ChIP) assay } \\
\text { (promoter-binding) }[111,113]\end{array}$ & $\begin{array}{l}\text { - Luciferase reporter assay is commonly used to study } \\
\text { gene expression at the transcriptional level. } \\
\text { - ChIP allows for the specific study of molecular } \\
\text { regulation and induction of mucin expression under } \\
\text { various conditions. }\end{array}$ & $\begin{array}{l}\text { - Most applicable in cell cultures. } \\
\text { - Does not give quantitative information on } \\
\text { mucin expression or secretion. }\end{array}$ \\
\hline $\begin{array}{l}\text { Using transgenic or knockout } \\
\text { animals }[89,114,115]\end{array}$ & $\begin{array}{l}\text { - Unique and valuable information on the overall } \\
\text { function and/or effects of overexpression/depletion } \\
\text { of each mucin throughout the lifespan of an animal } \\
\text { model. } \\
\text { - Can be used for determination and verification of } \\
\text { mucin-regulation pathways. }\end{array}$ & $\begin{array}{l}\text { - Most often applied in rodents. } \\
\text { - Often have to be used in tandem with other } \\
\text { techniques to verify the effect. } \\
\text { - Depending on the model species, can be } \\
\text { expensive, time-consuming. }\end{array}$ \\
\hline
\end{tabular}


Table 4 Advantages and limitations of quantitative and semi-quantitative protein detection methods for mucus/mucin measurement

\begin{tabular}{|c|c|c|}
\hline Method & Advantages & Limitations \\
\hline $\begin{array}{l}\text { Percent solid } \\
\text { matter }[13,88]\end{array}$ & $\begin{array}{l}\text { - Used for quantitative determination of mucus viscosity } \\
\text { and water/solids ratio by measurement of the decrease } \\
\text { in weight of mucus samples after oven drying. } \\
\text { - Simple and inexpensive. }\end{array}$ & $\begin{array}{l}\text { - Not an exact measurement of mucin, as the percent } \\
\text { dry matter may increase/decrease due to changes in } \\
\text { non-mucin molecules (e.g. inflammatory-cell derived } \\
\text { products). }\end{array}$ \\
\hline ELISA $[117,118]$ & $\begin{array}{l}\text { - Simple and relatively sensitive detection/quantitation } \\
\text { of proteins in liquid samples. } \\
\text { - Can be used for in vivo collected sputum and ASL. }\end{array}$ & $\begin{array}{l}\text { - Antibody needs to be specific for mucin of interest } \\
\text { and epitope should avoid homologous regions/repeats } \\
\text { between mucins. } \\
\text { - A purified species-specific mucin standard should be } \\
\text { used, which is not always available. }\end{array}$ \\
\hline $\begin{array}{l}\text { SDS-PAGE/ } \\
\text { western blot } \\
\text { assay }[100,119]\end{array}$ & $\begin{array}{l}\text { - Inexpensive and relatively accurate measurement of } \\
\text { specific proteins in liquid samples and tissue } \\
\text { homogenates. } \\
\text { - Can be used together with housekeeping molecules } \\
\text { for proper quantitation. } \\
\text { - Allows for the detection of normal and modified forms } \\
\text { of the same protein (after stripping of initial labeling) }\end{array}$ & $\begin{array}{l}\text { - Antibody needs to be specific for mucin of interest and } \\
\text { epitope should avoid homologous regions/repeats } \\
\text { between mucins. } \\
\text { - Requires denaturation of mucins for running on SDS-PAGE } \\
\text { gels or agarose gels for proper separation of the larger } \\
\text { molecules. }\end{array}$ \\
\hline $\begin{array}{l}\text { Dot-blot (Slot- } \\
\text { blot) assays [120] }\end{array}$ & $\begin{array}{l}\text { - Inexpensive and quick alternative to western blots } \\
\text { for antibody comparison and assessment in a large } \\
\text { number of samples. }\end{array}$ & $\begin{array}{l}\text { - Does not separate proteins by size. } \\
\text { - Not as sensitive as western blot (quantification is based on } \\
\text { intensity image analysis of dots). } \\
\text { - Does not typically utilize housekeeping proteins to } \\
\text { normalize the signal intensity. }\end{array}$ \\
\hline
\end{tabular}

These techniques are appealing because of their direct measurement of mucin and because of their quantitative nature. Further, the equipment required to do these types of experiments is fairly standard. Some limitations include the laborious methods required to isolate mucin (highlighted below), as well as the potential to not obtain an adequate sample volume. There are also specific technical considerations for ELISA procedures that are contingent upon the method used. For example, an absorption ELISA requires that the antigen be immobilized to a plastic surface and detected with an antibody, whereas a sandwich ELISA captures the antigen using an antibodycoated surface and then detects the antigen using another antibody [121, 122]. Although the absorption ELISA is simpler and less-time consuming, mucins absorption to a plastic surface requires a modified surface, which then enables the absorption of reduced mucin proteins $[65,123]$. On the other hand, the sandwich ELISA offers greater sensitivity and specificity but is more time-consuming and laborious [122]. Additional approaches for examining mucus and mucins at the protein level include measuring percent solids [13, 88], dot-blot assays [120] and proteomics [124-126]. Although percent solids and dot-blot assays are simpler, they are less informative and less sensitive. Proteomics, on the other hand, is highly sensitive and a powerful tool to interrogate mucus. It can provide information regarding the relative abundance and types of proteins present in a mucus sample [127]. Proteomics also provides information regarding biochemical properties of mucins, as highlighted below.

\section{Measurement of biophysical/biochemical properties (Fig.}

\section{2, Table 5)}

The biophysical and biochemical properties of mucus are most affected by its composition, and greatly impact the ability of mucus to be cleared out of the airway. Thus, there is great interest in understanding the biophysical and biochemical properties of mucus and mucin. Historically, studying mucin requires rigorous and tedious isolation, solubilization and purification procedures [128, 129, 138-140]. Early in vitro studies relied predominantly on cesium bromide density gradients and sephadex chromatography, alone or coupled with proteolytic digestion and/or denaturing agents [128-130], which provides information about its biochemical properties and structure. An advantage of chromatography is that it provides valuable information on mucin molecular charge and size $[128,129,136]$. Further, through additional processing using traditional (e.g., Edman degradation [141]) or more advanced techniques (e.g., mass-spectrometry [142, 143]), glycosylation patterns of mucins can be resolved [13]. This is important because glycosylation patterns greatly impact the biophysical nature of mucins, as the O-glycosylation of the protein backbones has been shown to induce higher molecular rigidity and extended conformation [15, 27]. This change in rigidity is due to the polyanionic and dielectric properties of the sulfated and sialic sugars, especially when introduced repeatedly in the heavily glycosylated tandem repeat regions of mucins [27]. Additionally, the heavy glycosylation of mucins has been linked to 
Table 5 Advantages and limitations of methods and techniques used for measuring biochemical and biophysical mucus properties

\begin{tabular}{|c|c|c|}
\hline Method & Advantages & Limitations \\
\hline $\begin{array}{l}\text { Isolation, fractionation and purification } \\
\text { of mucins [128-130] }\end{array}$ & $\begin{array}{l}\text { - Required steps for all initial molecular/biochemical } \\
\text { characterizations. }\end{array}$ & $\begin{array}{l}\text { - Labor intensive and may be expensive. } \\
\text { - Loss of sample during the process, and } \\
\text { therefore cannot be used solely for } \\
\text { quantification purposes. } \\
\text { - Care must be taken that the mucins do } \\
\text { not become degraded. }\end{array}$ \\
\hline $\begin{array}{l}\text { Glycosylation analysis [17] and mass } \\
\text { spectrometry [127]. }\end{array}$ & $\begin{array}{l}\text { - Provides valuable information on species- and organ- } \\
\text { specific glycosylation and post-transcriptional modifi } \\
\text { cations of mucins. } \\
\text { - Precise qualitative and quantitative information on } \\
\text { different molecules in the sample, most often proteins } \\
\text { and carbohydrates. }\end{array}$ & $\begin{array}{l}\text { - Expensive system and materials. } \\
\text { - Identification of proteins/molecules } \\
\text { require protein libraries for each animal } \\
\text { species of interest and knowledge about } \\
\text { glycosylation sites. }\end{array}$ \\
\hline $\begin{array}{l}\text { Viscoelasticity of mucus (laser/light } \\
\text { scattering analysis [131], direct } \\
\text { rheometry [132], and fluorescence } \\
\text { recovery after photobleaching (FRAP) } \\
{[13,133-135] \text { ) }}\end{array}$ & $\begin{array}{l}\text { - Laser scattering or quasi-elastic (dynamic) scattering is } \\
\text { used specifically for molecular size distribution and for } \\
\text { mucin conformation and chain dimensions analysis. } \\
\text { - FRAP assay is easily applicable for in vitro/ex vivo } \\
\text { studies. } \\
\text { - Viscosity/elasticity under shear stress conditions can be } \\
\text { done directly in rheometer machines but requires higher } \\
\text { amounts of sample. }\end{array}$ & $\begin{array}{l}\text { - Use mathematical modeling equations } \\
\text { to calculate the viscoelasticity, which } \\
\text { can introduce errors if not performed } \\
\text { or calculated correctly. } \\
\text { - They do not give information on the } \\
\text { quantity or specificity of single mucin } \\
\text { component. } \\
\text { - FRAP and other microrheology techniques } \\
\text { depend on the diameter and non- } \\
\text { adhesiveness of labelled particles used. }\end{array}$ \\
\hline $\begin{array}{l}\text { Chromatography separation and } \\
\text { detection }[128,129,136]\end{array}$ & $\begin{array}{l}\text { - specific technique for separation and molecular analysis } \\
\text { of biological substances. } \\
\text { - Provides information on molecular charge and size. }\end{array}$ & $\begin{array}{l}\text { - Chromatography is expensive and labor- } \\
\text { intensive. } \\
\text { - If radioactive detection use, handling and } \\
\text { disposal, is expensive and environmentally } \\
\text { unfriendly. }\end{array}$ \\
\hline $\begin{array}{l}\text { Metabolic labeling/ Radiolabel } \\
\text { discharge measurement or } \\
\text { autoradiography }[129,137] \text {. }\end{array}$ & 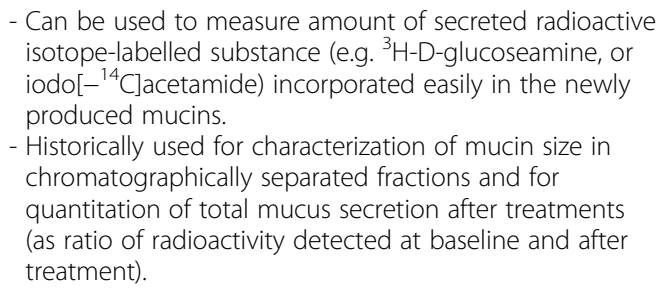 & $\begin{array}{l}\text { - Requires radioactive substance handling } \\
\text { and exposure. } \\
\text { - Materials are strictly regulated and } \\
\text { expensive to dispose of. } \\
\text { - Not very sensitive to specific mucin secretion. } \\
\text { - Applicable only in vitro/ex vivo and on } \\
\text { sputum samples from patients. }\end{array}$ \\
\hline
\end{tabular}

increased hydration of the molecules, giving them their gel-like properties, and are critical in establishing their rheological properties (from flexible to rigid and brittle) [27, 144].

Radiolabeling (metabolic labeling) of mucins also provides information regarding the total release of glycoproteins, as well as the functional state of the secreting cells $[128,129,137,140,145,146]$. When radio-labeled monosaccharides (such as fucose) are used, they can also additional more specific information regarding glycosylation [129, 137]. Although, radio-isotope incorporating techniques were essential in initial characterization studies of mucins, they are growing less popular.

Most early mucin characterization studies have focused on the physical and rheological properties of purified mucins (molecular weight, elasticity, light scattering and sedimentation velocity), as well as on the biochemical properties ( $\mathrm{pH}$, amino-acid and monosaccharide-moiety composition) [17, 130, 132, 138, 147, 148]. The rheological properties of mucins are among the most important determinants for proper MCT $[27,148]$, and they are highly dependent not only on the relative ratios of the different mucins and their biochemical features, but also on the properties of the solvent and other proteins or salts. Together, these molecules interact with mucins to form the mesh structure of the mucus gel layer $[27,148]$. The normal properties of mucus are those of a viscous liquid under high shear rates, and of an elastic solid at low shear rates [148]. Classical direct rheometry techniques, make use of special instruments like the cone-and-plate rheometer, the capillary viscometer, or the filancemeter, which rely on the subjection of collected mucus samples to known forces like shear rate, torque, strain or traction $[132,148]$. As a result, they enable the measurement and calculation of viscosity and elasticity under different conditions [148]. Light or laser scattering techniques utilize frequency shift and multiangle scattering of a light (laser) beam from moving molecules in samples, and the collected data gives information of the absolute molar mass and the average size of mucins in solution [100, 130, 147]. It has also been shown to be useful in the assessment of the motility of respiratory cilia [131]. 
The aforementioned methods described the macrorheology of mucus. However, the microrheological properties of the mucus gel layer are also of interest, and can provide significant information on the mesh-pore size and thus penetrability of infectious, toxic or other agents into the gel, as well as the mucus viscoelasticity [148]. Visuallybased techniques like the fluorescence recovery after photobleaching (FRAP) assay are used to determine the viscosity of mucus by measuring the two-dimensional lateral diffusion of a thin film of a FITC labelled dextran powder (or other fluorescent molecules) applied on the mucus surface, and its fluorescence recovery time after light exposure [13, 133-135]. This technique is especially applicable in ciliated epithelial cultures or tracheal explants [13, 133-135] or on freshly collected mucus samples [13]. Similar to the other visual techniques described earlier, factors like molecular/particle size and adhesiveness, pH-sensitivity, photostability and brightness [148] need to be accounted for when using FRAP. Further, careful consideration of the mathematical models used to calculate the rheological properties is necessary for proper and rigorous evaluation [149].

\section{Conclusions}

The heterogeneous nature of mucus glycoproteins, their large molecular sizes and complex intermolecular interactions, continues to make studies aimed at elucidating mucin production, secretion, abundance, and biophysical properties, challenging [49-51, 148]. Despite these challenges, there are numerous techniques available to study mucus and mucin, each with distinct advantages and limitations.

For example, purification methods are laborious while radiolabeling methods are expensive and pose health and environmental risks. Thus, these techniques are generally in decline and would benefit from a refined methodology. ELISA methods based on antibody detection remain a relatively inexpensive method to detect mucin concentrations in patient sputum, BAL and other body fluids $[117,118]$, but require mucin-specific antibodies (e.g., MUC5AC vs. MUC5B). Western blot methods are also useful for detection of non-gel-forming mucins in biological fluids and tissues [100, 119], but can require labor intensive solubilization and purification to allow for adequate separation during gel-electrophoresis. Proper detection in western blots also depends on the availability of species-specific mucin-labeling antibodies.

Histological and immunocytochemical imaging methods remain gold standards for detection of goblet cell hyperplasia/metaplasia, mucus plugging, localization of non-secreted mucins or co-localization of mucins with other molecules in vitro, ex vivo or post mortem [90, 92, 93, 95, 100], but may be more difficult to utilize in vivo [91] or in patients [20]. They are also limited in that they provide episodic information about a specific point in time. Thus, there has been a push to develop imaging methods that can be implemented in vivo that allow for capturing of dynamic information. Consistent with that, several advances in imaging techniques, including Xray synchrotron [96] and quazi-monochromatic X-ray phase-contrast imaging [1], have been applied successfully to measure MCT and mucus plugs in vivo.

Molecular and genetic methods, and particularly RNA extraction with RT-PCR, have also become increasingly utilized for the detection of changes in expression levels of mucins [110-112]. They are also useful for the detection of downstream and upstream mechanisms in the regulation of mucin expression/secretion [111, 113]. As mentioned, genetically engineered rodent models have provided unprecedented insight into the role of Muc5AC and Muc5B in airway health and disease [89, $114,115]$. Because of species differences in mucin and airway physiology and anatomy [51], it is worthwhile and recommended that additional animal models be explored.

The biophysical and biochemical properties of mucus can be assessed using many different approaches. Although separation chromatography was used frequently during many of the initial glycobiology studies [128-130, 136], pairing chromatography with more recent technology, such as mass spectrometry, has become increasingly popular [13, 127]. Additionally, the gold standard for measuring viscoelastic properties of mucus is direct rheometry, but these methods typically require a significant volume of mucus and are limited to in vitro studies [17, 148]. Thus, FRAP as a tool to measure viscoelastic properties has become an effective and valuable approach that has fewer volume limitations [13, 133-135, 148]. The development of a nanoprobe to measure the biophysical properties of mucus in vivo in a somewhat non-invasive manner could significantly enhance the field. For example, the fabrication of flagellated nanobots inspired by bacteria has been reported $[150,151]$. Thus, it is possible that flagellated nanobots or some iteration of flagellated nanobots might offer new approach to measure the viscoelastic properties of mucus and mucins.

Multiple strategies are required to study mucus and mucins. The strength of using a multi-strategy approach is the reduction in errors that are likely to occur by using a single technique. Unfortunately, many aspects of mucin regulation are still unclear, especially on the scale of longitudinal changes in mucus properties within the same subject or patient. Thus, though great leaps in technology over the past few decades have been made, there is still a need for the development of fast and easy method(s) for detection and quantitation of mucins and mucus, especially as it relates to clinical samples and in patients. 


\section{Abbreviations}

AB/PAS: Alcian Blue; AREST CF: Australian Respiratory Early Surveillance Team for Cystic Fibrosis; ASL: Airway surface liquid; ChIP: Chromatin immunoprecipitation; COPD: Chronic obstructive pulmonary disease; e.g.: Exempli gratia (for example); ELISA: Enzyme-linked Immunosorbent assay; FEV1: Forced expiratory volume in $1 \mathrm{~s}$; FITC: Fluorescein isothiocyanate; FRAP: Fluorescence recovery after photobleaching; MCT: Mucociliary transport; mRNA: Messenger ribonucleic acid; MUC: Human mucin (denoted with the number after MUC); muc5AC: Mucin 5 AC; muc5B: Mucin 5B; NHLBI: National Heart, Lung, and Blood Institute; PAS: Periodic Acid-Schiff stain; PCL: Periciliary layer; RT-PCR: Reverse transcription polymerase chain reaction; SDS-PAGE: Sodium dodecyl sulfate polyacrylamide gel electrophoresis; SPIROMICS: Subpopulations and Intermediate Outcome Measures in COPD Study

\section{Acknowledgements}

The authors are grateful to Maria Guevara for helpful technical assistance.

\section{Authors' contributions}

LRR and KRA read and interpreted available literature for the review. LRR and KRA generated tables and figures. LRR and KRA wrote and edited the manuscript. Both authors read and approved the final manuscript.

\section{Funding}

This study has been funded by NHLBI (HL119560, Reznikov, Pl; OD023854, Reznikov (o-I).

\section{Availability of data and materials}

All data generated or analyzed during this study are included in this published article.

\section{Ethics approval and consent to participate}

Not applicable.

\section{Consent for publication}

Not applicable.

\section{Competing interests}

The authors declare that they have no competing interests.

Received: 21 March 2019 Accepted: 11 November 2019 Published online: 21 November 2019

\section{References}

1. Dunican EM, Elicker BM, Gierada DS, Nagle SK, Schiebler ML, Newell JD, Raymond WW, Lachowicz-Scroggins ME, Di Maio S, Hoffman EA, et al. Mucus plugs in patients with asthma linked to eosinophilia and airflow obstruction. J Clin Invest. 2018;128:997-1009.

2. Burgel PR, Montani D, Danel C, Dusser DJ, Nadel JA. A morphometric study of mucins and small airway plugging in cystic fibrosis. Thorax. 2007;62:153-61.

3. Williams OW, Sharafkhaneh A, Kim V, Dickey BF, Evans CM. Airway mucus: from production to secretion. Am J Respir Cell Mol Biol. 2006;34:527-36.

4. Turkovic L, Caudri D, Rosenow T, Hall G, Stick S. Presence of mucus plugging is predictive of long term lung function in children with cystic fibrosis. Eur Respir J. 2017:50:OA4401.

5. Widdicombe $\mathrm{JH}$. Regulation of the depth and composition of airway surface liquid. J Anat. 2002:201:313-8.

6. Tarran R. Regulation of airway surface liquid volume and mucus transport by active ion transport. Proc Am Thorac Soc. 2004;1:42-6.

7. Ma J, Rubin BK, Voynow JA: Mucins, Mucus, and Goblet Cells. Chest 2017

8. Webster MJ, Tarran R: Chapter Nine - Slippery When Wet: Airway Surface Liquid Homeostasis and Mucus Hydration. In Current Topics in Membranes. Volume 81. Edited by Levitane I, Delpire E, Rasgado-Flores H: Academic Press; 2018: 293-335.

9. Wu DX, Lee CY, Uyekubo SN, Choi HK, Bastacky SJ, Widdicombe JH. Regulation of the depth of surface liquid in bovine trachea. Am J Phys. 1998;274:L388-95.

10. Kreda SM, Okada SF, van Heusden CA, O'Neal W, Gabriel S, Abdullah L, Davis CW, Boucher RC, Lazarowski ER. Coordinated release of nucleotides and mucin from human airway epithelial Calu-3 cells. J Physiol. 2007;584: 245-59.

11. Plasschaert LW, Zilionis R, Choo-Wing R, Savova V, Knehr J, Roma G, Klein $A M$, Jaffe AB. A single-cell atlas of the airway epithelium reveals the CFTRrich pulmonary ionocyte. Nature. 2018;560:377-81.

12. Montoro DT, Haber AL, Biton M, Vinarsky V, Lin B, Birket SE, Yuan F, Chen S, Leung HM, Villoria J, et al. A revised airway epithelial hierarchy includes CFTR-expressing ionocytes. Nature. 2018;560:319-24.

13. Tang XX, Ostedgaard LS, Hoegger MJ, Moninger TO, Karp PH, McMenimen JD, Choudhury B, Varki A, Stoltz DA, Welsh MJ. Acidic pH increases airway surface liquid viscosity in cystic fibrosis. J Clin Invest. 2016;126:879-91.

14. Bansil R, Turner BS. The biology of mucus: composition, synthesis and organization. Adv Drug Deliv Rev. 2018;124:3-15.

15. Gum JR. Mucin genes and the proteins they encode: structure, diversity, and regulation. Am J Respir Cell Mol Biol. 1992;7:557-64.

16. Dhanisha SS, Guruvayoorappan C, Drishya S, Abeesh P. Mucins: structural diversity, biosynthesis, its role in pathogenesis and as possible therapeutic targets. Crit Rev Oncol Hematol. 2018;122:98-122.

17. Thornton DJ, Sheehan JK, Carlstedt I. Heterogeneity of mucus glycoproteins from cystic fibrotic sputum. Are there different families of mucins? Biochem J. 1991;276(Pt 3):677-82

18. Boucher RC, Cotton CU, Gatzy JT, Knowles MR, Yankaskas JR. Evidence for reduced $\mathrm{Cl}$ - and increased $\mathrm{Na}+$ permeability in cystic fibrosis human primary cell cultures. J Physiol. 1988;405:77-103.

19. Quinton PM. Role of epithelial HCO3(-) transport in mucin secretion: lessons from cystic fibrosis. Am J Physiol Cell Physiol. 2010;299:C1222-33.

20. Hoegger MJ, Fischer AJ, McMenimen JD, Ostedgaard LS, Tucker AJ, Awadalla MA, Moninger TO, Michalski AS, Hoffman EA, Zabner J, et al. Impaired mucus detachment disrupts mucociliary transport in a piglet model of cystic fibrosis. Science. 2014;345:818-22.

21. Henke MO, John G, Germann M, Lindemann H, Rubin BK. MUC5AC and MUC5B mucins increase in cystic fibrosis airway secretions during pulmonary exacerbation. Am J Respir Crit Care Med. 2007;175:816-21.

22. Christenson SA, van den Berge M, Faiz A, Inkamp K, Bhakta N, Bonser LR, Zlock LT, Barjaktarevic IZ, Barr RG, Bleecker ER, et al. An airway epithelial IL$17 \mathrm{~A}$ response signature identifies a steroid-unresponsive COPD patient subgroup. J Clin Invest. 2019;129:169-81.

23. Kesimer M, Ford AA, Ceppe A, Radicioni G, Cao R, Davis CW, Doerschuk CM, Alexis NE, Anderson WH, Henderson AG, et al. Airway Mucin concentration as a marker of chronic bronchitis. N Engl J Med. 2017;377:911-22.

24. Lai T, Wu D, Chen M, Cao C, Jing Z, Huang L, Lv Y, Zhao X, Lv Q, Wang Y, et al. YKL-40 expression in chronic obstructive pulmonary disease: relation to acute exacerbations and airway remodeling. Respir Res. 2016;17:31.

25. Saetta M, Turato G, Baraldo S, Zanin A, Braccioni F, Mapp CE, Maestrelli P, Cavallesco G, Papi A, Fabbri LM. Goblet cell hyperplasia and epithelial inflammation in peripheral airways of smokers with both symptoms of chronic bronchitis and chronic airflow limitation. Am J Respir Crit Care Med. 2000;161:1016-21.

26. Dransfield MT, Wilhelm AM, Flanagan B, Courville C, Tidwell SL, Raju SV, Gaggar A, Steele C, Tang LP, Liu B, Rowe SM. Acquired cystic fibrosis transmembrane conductance regulator dysfunction in the lower airways in COPD. Chest. 2013;144:498-506.

27. Verdugo P. Supramolecular dynamics of mucus. Cold Spring Harb Perspect Med. 2012;2.

28. Gendler SJ, Spicer AP. Epithelial mucin genes. Annu Rev Physiol. 1995:57:607-34.

29. Verdugo P. Goblet cells secretion and mucogenesis. Annu Rev Physiol. 1990; 52:157-76.

30. Thornton DJ, Rousseau K, McGuckin MA. Structure and function of the polymeric mucins in airways mucus. Annu Rev Physiol. 2008;70:459-86.

31. Kesimer M, Makhov AM, Griffith JD, Verdugo P, Sheehan JK. Unpacking a gel-forming mucin: a view of MUC5B organization after granular release. Am J Physiol Lung Cell Mol Physiol. 2010;298:L15-22.

32. Ermund A, Trillo-Muyo S, Hansson GC. Assembly, release, and transport of airway Mucins in pigs and humans. Annals of the American Thoracic Society. 2018;15:S159-63.

33. Evans CM, Kim K, Tuvim MJ, Dickey BF. Mucus hypersecretion in asthma: causes and effects. Curr Opin Pulm Med. 2009;15:4-11.

34. Copin MC, Buisine MP, Devisme L, Leroy X, Escande F, Gosselin B, Aubert JP, Porchet N. Normal respiratory mucosa, precursor lesions and lung carcinomas: differential expression of human mucin genes. Front Biosci. 2001;6:D1264-75. 
35. Hovenberg HW, Davies JR, Herrmann A, Lindén CJ, Carlstedt I. MUC5AC, but not MUC2, is a prominent mucin in respiratory secretions. Glycoconj J. 1996; 13:839-47.

36. Zhu L, Lee $P$, Yu D, Tao S, Chen Y. Cloning and characterization of human MUC19 gene. Am J Respir Cell Mol Biol. 2011;45:348-58.

37. Chen $Y$, Zhao YH, Kalaslavadi TB, Hamati E, Nehrke K, Le AD, Ann DK, Wu R. Genome-wide search and identification of a novel gel-forming mucin MUC19/ Muc19 in glandular tissues. Am J Respir Cell Mol Biol. 2004;30:155-65.

38. Vieira VG, Prolla JC. Clinical evaluation of eosinophils in the sputum. J Clin Pathol. 1979;32:1054-7.

39. Thompson AB, Bohling T, Payvandi F, Rennard SI. Lower respiratory tract lactoferrin and lysozyme arise primarily in the airways and are elevated in association with chronic bronchitis. J Lab Clin Med. 1990;115:148-58.

40. Bousquet J, Chanez P, Lacoste JY, Barneon G, Ghavanian N, Enander I, Venge P, Ahlstedt S, Simony-Lafontaine J, Godard P, et al. Eosinophilic inflammation in asthma. N Engl J Med. 1990;323:1033-9.

41. Petsky HL, Cates CJ, Kew KM, Chang AB. Tailoring asthma treatment on eosinophilic markers (exhaled nitric oxide or sputum eosinophils): a systematic review and meta-analysis. Thorax. 2018;73:1110-9.

42. Moore WC, Hastie AT, Li X, Li H, Busse WW, Jarjour NN, Wenzel SE, Peters SP, Meyers DA, Bleecker ER, et al. Sputum neutrophil counts are associated with more severe asthma phenotypes using cluster analysis. J Allergy Clin Immunol. 2014;133:1557-63 e1555.

43. Margaroli C, Garratt LW, Horati H, Dittrich AS, Rosenow T, Montgomery ST, Frey DL, Brown MR, Schultz C, Guglani L, et al. Elastase exocytosis by airway neutrophils is associated with early lung damage in children with cystic fibrosis. Am J Respir Crit Care Med. 2019;199:873-81.

44. Heron M, Grutters JC, ten Dam-Molenkamp KM, Hijdra D, van HeugtenRoeling A, Claessen AM, Ruven HJ, van den Bosch JM, van Velzen-Blad H. Bronchoalveolar lavage cell pattern from healthy human lung. Clin Exp Immunol. 2012;167:523-31.

45. Guiedem E, Ikomey GM, Nkenfou C, Walter PE, Mesembe M, Chegou NN, Jacobs GB, Okomo Assoumou MC. Chronic obstructive pulmonary disease (COPD): neutrophils, macrophages and lymphocytes in patients with anterior tuberculosis compared to tobacco related COPD. BMC Res Notes. 2018;11:192.

46. Potter JL, Spector S, Matthews LW, Lemm J. Studies on pulmonary secretions. 3. The nucleic acids in whole pulmonary secretions from patients with cystic fibrosis, bronchiectasis, and laryngectomy. Am Rev Respir Dis. 1969:99:909-16.

47. Neeli I, Khan SN, Radic M. Histone deimination as a response to inflammatory stimuli in neutrophils. J Immunol. 2008;180:1895-902.

48. Efthimiadis A, Spanevello A, Hamid Q, Kelly MM, Linden M, Louis R, Pizzichini MMM, Pizzichini E, Ronchi C, Van Overveld F, Djukanovic R. Methods of sputum processing for cell counts, immunocytochemistry and in situ hybridisation. Eur Respir J. 2002;20:19s-23s.

49. Jackson A, Kemp P, Giddings J, Sugar R. Development and validation of a lectin-based assay for the quantitation of rat respiratory mucin. Novartis Found Symp. 2002;248:94-112.

50. Hilgers J, von Mensdorff-Pouilly S, Verstraeten AA, Kenemans P. Quantitation of polymorphic epithelial mucin: a challenge for biochemists and immunologists. Scand J Clin Lab Invest Suppl. 1995;221:81-6.

51. Rose MC, Piazza FM, Chen YA, Alimam MZ, Bautista MV, Letwin N, Rajput B. Model systems for investigating mucin gene expression in airway diseases. J Aerosol Med. 2000;13:245-61.

52. Wine JJ. Parasympathetic control of airway submucosal glands: central reflexes and the airway intrinsic nervous system. Auton Neurosci. 2007; 133:35-54.

53. Reznikov LR, Liao YSJ, Gu T, Davis KM, Kuan SP, Atanasova KR, Dadural JS, Collins EN, Guevara MV, Vogt K. Sex-specific airway hyperreactivity and sexspecific transcriptome remodeling in neonatal piglets challenged with intraairway acid. Am J Physiol Lung Cell Mol Physiol. 2019;316:L131-43.

54. Mall MA. Unplugging mucus in cystic fibrosis and chronic obstructive pulmonary disease. Ann Am Thorac Soc. 2016;13(Suppl 2):S177-85.

55. Cho HJ, Joo NS, Wine JJ. Mucus secretion from individual submucosal glands of the ferret trachea. Am J Physiol Lung Cell Mol Physiol. 2010; 299:L124-36.

56. Ohtsuka R, Doi K, Itagaki S. Histological characteristics of respiratory system in Brown Norway rat. Exp Anim. 1997;46:127-33.

57. Desseyn JL, Aubert JP, Porchet N, Laine A. Evolution of the large secreted gel-forming mucins. Mol Biol Evol. 2000;17:1175-84.
58. Fogg FJJ, Hutton DA, Jumel K, Pearson JP, Harding SE, Allen A. Characterization of pig colonic mucins. Biochem J. 1996;316:937-42.

59. Padra M, Adamczyk B, Benktander J, Flahou B, Skoog EC, Padra JT, Smet A, Jin CS, Ducatelle R, Samuelsson T, et al. Helicobacter suis binding to carbohydrates on human and porcine gastric mucins and glycolipids occurs via two modes. Virulence. 2018;9:898-918.

60. Takeyama K, Jung B, Shim JJ, Burgel PR, Dao-Pick T, Ueki IF, Protin U, Kroschel P, Nadel JA. Activation of epidermal growth factor receptors is responsible for mucin synthesis induced by cigarette smoke. Am J Physiol Lung Cell Mol Physiol. 2001;280:L165-72.

61. Jeffries JL, Jia J, Choi W, Choe S, Miao J, Xu Y, Powell R, Lin J, Kuang Z, Gaskins HR, Lau GW. Pseudomonas aeruginosa pyocyanin modulates mucin glycosylation with sialyl-Lewis $(x)$ to increase binding to airway epithelial cells. Mucosal Immunol. 2016;9:1039-50.

62. Fahy JV, Dickey BF. Airway mucus function and dysfunction. N Engl J Med. 2010;363:2233-47.

63. Davis CW. Regulation of mucin secretion from in vitro cellular models Novartis Found Symp. 2002;248:113-25 discussion 125-131, 277-182.

64. Kemp PA, Sugar RA, Jackson AD. Nucleotide-mediated mucin secretion from differentiated human bronchial epithelial cells. Am J Respir Cell Mol Biol. 2004;31:446-55.

65. Abdullah LH, Wolber C, Kesimer M, Sheehan JK, Davis CW. Studying mucin secretion from human bronchial epithelial cell primary cultures. Methods Mol Biol. 2012;842:259-77.

66. Kesimer M, Kirkham S, Pickles RJ, Henderson AG, Alexis NE, Demaria G, Knight D, Thornton DJ, Sheehan JK. Tracheobronchial air-liquid interface cell culture: a model for innate mucosal defense of the upper airways? Am J Physiol Lung Cell Mol Physiol. 2009;296:L92-L100.

67. Weynants P, Cordier JF, Cellier CC, Pages J, Loire R, Brune J. Primary immunocytoma of the lung: the diagnostic value of bronchoalveolar lavage. Thorax. 1985;40:542-3.

68. Andreasson AS, Karamanou DM, Gillespie CS, Ozalp F, Butt T, Hill P, Jiwa K, Walden HR, Green NJ, Borthwick LA, et al. Profiling inflammation and tissue injury markers in perfusate and bronchoalveolar lavage fluid during human ex vivo lung perfusion. Eur J Cardiothorac Surg. 2017;51:577-86.

69. Reynolds HY, Newball HH. Analysis of proteins and respiratory cells obtained from human lungs by bronchial lavage. J Lab Clin Med. 1974;84:559-73.

70. Technical recommendations and guidelines for bronchoalveolar lavage (BAL). Report of the European Society of Pneumology Task Group. Eur Respir J. 1989:2:561-85.

71. Leaker BR, Nicholson GC, Ali FY, Daudi N, O'Connor BJ, Barnes PJ. Bronchoabsorption; a novel bronchoscopic technique to improve biomarker sampling of the airway. Respir Res. 2015;16:102.

72. Bartoli ML, Bacci E, Carnevali S, Cianchetti S, Dente FL, Di Franco A, Giannini D, Taccola M, Vagaggini B, Paggiaro PL. Quality evaluation of samples obtained by spontaneous or induced sputum: comparison between two methods of processing and relationship with clinical and functional findings. J Asthma. 2002;39:479-86.

73. Weiszhar Z, Horvath I. Induced sputum analysis: step by step. Breathe. 2013; 9:300-6.

74. in't Veen JC, de Gouw HW, Smits HH, Sont JK, Hiemstra PS, Sterk PJ, Bel EH. Repeatability of cellular and soluble markers of inflammation in induced sputum from patients with asthma. Eur Respir J. 1996;9:2441-7.

75. Pizzichini MM, Popov TA, Efthimiadis A, Hussack P, Evans S, Pizzichini E, Dolovich J, Hargreave FE. Spontaneous and induced sputum to measure indices of airway inflammation in asthma. Am J Respir Crit Care Med. 1996; 154:866-9.

76. Hall GJ, Gandevia B. Relationship of the loose cough sign to daily sputum volume. Observer variation in its detection. Br J Prev Soc Med. 1971:25:109-13.

77. Kamin W, Klar-Hlawatsch B, Truebel H. Easy removal of a large mucus plug with a flexible paediatric bronchoscope after administration of rhDNase (Pulmozyme). Klin Padiatr. 2006;218:88-91.

78. Berra L, Coppadoro A, Bittner EA, Kolobow T, Laquerriere P, Pohlmann JR, Bramati S, Moss J, Pesenti A. A clinical assessment of the mucus shaver: a device to keep the endotracheal tube free from secretions. Crit Care Med. 2012:40:119-24.

79. Li Bassi G, Zanella A, Cressoni M, Stylianou M, Kolobow T. Following tracheal intubation, mucus flow is reversed in the semirecumbent position: possible role in the pathogenesis of ventilator-associated pneumonia. Crit Care Med. 2008;36:518-25 
80. Rubin BK, Ramirez O, Zayas JG, Finegan B, King M. Collection and analysis of respiratory mucus from subjects without lung disease. Am Rev Respir Dis. 1990;141:1040-3

81. Du Rand IA, Blaikley J, Booton R, Chaudhuri N, Gupta V, Khalid S, Mandal S, Martin J, Mills J, Navani N, et al. British Thoracic Society guideline for diagnostic flexible bronchoscopy in adults: accredited by NICE. Thorax 2013;68(Suppl 1):i1-i44

82. Matute-Bello G, Downey G, Moore BB, Groshong SD, Matthay MA, Slutsky AS, Kuebler WM. Acute lung injury in animals study G: an official American Thoracic Society workshop report: features and measurements of experimental acute lung injury in animals. Am J Respir Cell Mol Biol. 2011; 44:725-38.

83. Vieira MO, Pizzichini E, Steidle LJ, da Silva JK, Pizzichini MM. Sputum induction in severe exacerbations of asthma: safety of a modified method. Eur Respir J. 2011;38:979-80.

84. Sagel SD, Chmiel JF, Konstan MW. Sputum biomarkers of inflammation in cystic fibrosis lung disease. Proc Am Thorac Soc. 2007:4:406-17.

85. Lapinsky SE. Endotracheal intubation in the ICU. Crit Care. 2015;19:258

86. Mietto C, Foley K, Salerno L, Oleksak J, Pinciroli R, Goverman J, Berra L. Removal of endotracheal tube obstruction with a secretion clearance device. Respir Care. 2014;59:e122-6.

87. Khelloufi M-K, Loiseau E, Jaeger M, Molinari N, Chanez P, Gras D, Viallat A. Spatiotemporal organization of cilia drives multiscale mucus swirls in model human bronchial epithelium. Sci Rep. 2018;8:2447.

88. Hill DB, Vasquez PA, Mellnik J, McKinley SA, Vose A, Mu F, Henderson AG, Donaldson SH, Alexis NE, Boucher RC, Forest MG. A biophysical basis for mucus solids concentration as a candidate biomarker for airways disease. PLoS One. 2014;9:e87681.

89. Ehre C, Worthington EN, Liesman RM, Grubb BR, Barbier D, O'Neal WK Sallenave J-M, Pickles RJ, Boucher RC. Overexpressing mouse model demonstrates the protective role of Muc5ac in the lungs. Proc Natl Acad Sci. 2012;109:16528-33.

90. Ermund A, Meiss LN, Rodriguez-Pineiro AM, Bahr A, Nilsson HE, Trillo-Muyo S, Ridley C, Thornton DJ, Wine JJ, Hebert H, et al. The normal trachea is cleaned by MUC5B mucin bundles from the submucosal glands coated with the MUC5AC mucin. Biochem Biophys Res Commun. 2017:492:331-7.

91. Rogers TD, Ostrowski LE, Livraghi-Butrico A, Button B, Grubb BR. Mucociliary clearance in mice measured by tracking trans-tracheal fluorescence of nasally aerosolized beads. Sci Rep. 2018:8:14744.

92. Ostedgaard LS, Moninger TO, McMenimen JD, Sawin NM, Parker CP Thornell IM, Powers LS, Gansemer ND, Bouzek DC, Cook DP, et al. Gelforming mucins form distinct morphologic structures in airways. Proc Natl Acad Sci U S A. 2017;114:6842-7.

93. Meyerholz DK, Lambertz AM, Reznikov LR, Ofori-Amanfo GK, Karp PH, McCray PB Jr, Welsh MJ, Stoltz DA. Immunohistochemical detection of markers for translational studies of lung disease in pigs and humans. Toxicol Pathol. 2016:44:434-41.

94. Rose MC, Voter WA, Brown CF, Kaufman B. Structural features of human tracheobronchial mucus glycoprotein. Biochem J. 1984;222:371-7.

95. Birket SE, Davis JM, Fernandez CM, Tuggle KL, Oden AM, Chu KK, Tearney GJ, Fanucchi MV, Sorscher EJ, Rowe SM. Development of an airway mucus defect in the cystic fibrosis rat. JCI Insight. 2018;3.

96. Donnelley M, Morgan KS, Awadalla M, Farrow NR, Hall C, Parsons DW. Highresolution mucociliary transport measurement in live excised large animal trachea using synchrotron X-ray imaging. Respir Res. 2017;18:95.

97. Gradl R, Dierolf M, Günther B, Hehn L, Möller W, Kutschke D, Yang L, Donnelley M, Murrie R, Erl A, et al. In vivo dynamic phase-contrast X-ray imaging using a compact light source. Sci Rep. 2018;8:6788.

98. Ramsey KA, Rosenow T, Turkovic L, Skoric B, Banton G, Adams AM, Simpson SJ, Murray C, Ranganathan SC, Stick SM, Hall GL. Lung clearance index and structural lung disease on computed tomography in early cystic fibrosis. Am J Respir Crit Care Med. 2016;193:60-7.

99. Kang JW, Lee YH, Kang MJ, Lee HJ, Oh R, Min HJ, Namkung W, Choi JY, Lee $\mathrm{SN}, \mathrm{Kim} \mathrm{CH}$, et al. Synergistic mucus secretion by histamine and IL-4 through TMEM16A in airway epithelium. Am J Physiol Lung Cell Mol Physiol. 2017;313:L466-76.

100. Thornton DJ, Carlstedt I, Howard M, Devine PL, Price MR, Sheehan JK. Respiratory mucins: identification of core proteins and glycoforms. Biochem J. 1996;316(Pt 3):967-75.

101. McGuckin MA, Thornton DJ. Detection and quantitation of mucins using chemical, lectin, and antibody methods. Methods Mol Biol. 2000;125:45-55.
102. Taylor CR, Levenson RM. Quantification of immunohistochemistry--issues concerning methods, utility and semiquantitative assessment II. Histopathology. 2006:49:411-24.

103. Walker RA. Quantification of immunohistochemistry--issues concerning methods, utility and semiquantitative assessment I. Histopathology. 2006;49: 406-10.

104. Meyerholz DK, Beck AP. Principles and approaches for reproducible scoring of tissue stains in research. Lab Investig. 2018;98:844-55.

105. Waters JC. Accuracy and precision in quantitative fluorescence microscopy. J Cell Biol. 2009;185:1135-48.

106. Meyerholz DK, Beck AP. Fundamental concepts for Semiquantitative tissue scoring in translational research. ILAR J. 2019.

107. Button B, Cai LH, Ehre C, Kesimer M, Hill DB, Sheehan JK, Boucher RC, Rubinstein M. A periciliary brush promotes the lung health by separating the mucus layer from airway epithelia. Science. 2012;337:937-41.

108. Robinson M, Bye PT. Mucociliary clearance in cystic fibrosis. Pediatr Pulmonol. 2002;33:293-306.

109. Foster WM, Walters DM, Longphre M, Macri K, Miller LM. Methodology for the measurement of mucociliary function in the mouse by scintigraphy. J Appl Physiol (1985). 2001;90:1111-7.

110. Zuhdi Alimam M, Piazza FM, Selby DM, Letwin N, Huang L, Rose MC. Muc$5 / 5$ ac mucin messenger RNA and protein expression is a marker of goblet cell metaplasia in murine airways. Am J Respir Cell Mol Biol. 2000;22:253-60.

111. Chen Y, Nickola TJ, DiFronzo NL, Colberg-Poley AM, Rose MC. Dexamethasone-mediated repression of MUC5AC gene expression in human lung epithelial cells. Am J Respir Cell Mol Biol. 2006;34:338-47.

112. Rousseau K, Kirkham S, McKane S, Newton R, Clegg P, Thornton DJ. Muc5b and Muc5ac are the major oligomeric mucins in equine airway mucus. Am J Physiol Lung Cell Mol Physiol. 2007;292:L1396-404.

113. Chen Y, Watson AM, Williamson CD, Rahimi M, Liang C, Colberg-Poley AM, Rose MC. Glucocorticoid receptor and histone deacetylase-2 mediate dexamethasone-induced repression of MUC5AC gene expression. Am J Respir Cell Mol Biol. 2012;47:637-44.

114. Roy MG, Livraghi-Butrico A, Fletcher AA, McElwee MM, Evans SE, Boerner RM, Alexander SN, Bellinghausen LK, Song AS, Petrova YM, et al. Muc5b is required for airway defence. Nature. 2014;505:412-6.

115. Evans CM, Raclawska DS, Ttofali F, Liptzin DR, Fletcher AA, Harper DN, McGing MA, McElwee MM, Williams OW, Sanchez E, et al. The polymeric mucin Muc5ac is required for allergic airway hyperreactivity. Nat Commun. 2015;6:6281.

116. Okuda K, Chen G, Subramani DB, Wolf M, Gilmore RC, Kato T, Radicioni G, Kesimer M, Chua M, Dang $H$, et al. Localization of secretory Mucins MUC5AC and MUC5B in Normal/healthy human airways. Am J Respir Crit Care Med. 2019;199:715-27.

117. Lin H, Carlson DM, St George JA, Plopper CG, Wu R. An ELISA method for the quantitation of tracheal mucins from human and nonhuman primates. Am J Respir Cell Mol Biol. 1989;1:41-8.

118. Yang PC, Luh KT, Kuo SH, Wu CW. Immunocytochemistry and ELISA quantitation of mucin for diagnosis of malignant pleural effusions. Am Rev Respir Dis. 1992;146:1571-5.

119. Ramsey KA, Rushton ZL, Ehre C. Mucin Agarose gel electrophoresis: Western blotting for high-molecular-weight glycoproteins. J Vis Exp. 2016.

120. Thornton DJ, Holmes DF, Sheehan JK, Carlstedt I. Quantitation of mucus glycoproteins blotted onto nitrocellulose membranes. Anal Biochem. 1989; 182:160-4.

121. Bamrungphon W, Prempracha N, Bunchu N, Rangdaeng S, Sandhu T, Srisukho S, Boonla C, Wongkham S. A new mucin antibody/enzyme-linked lectin-sandwich assay of serum MUC5AC mucin for the diagnosis of cholangiocarcinoma. Cancer Lett. 2007;247:301-8.

122. Sakamoto S, Putalun W, Vimolmangkang S, Phoolcharoen W, Shoyama Y, Tanaka $\mathrm{H}$, Morimoto S. Enzyme-linked immunosorbent assay for the quantitative/ qualitative analysis of plant secondary metabolites. J Nat Med. 2018;72:32-42

123. Gull I, Wirth M, Gabor F. Development of a sensitive and reliable ELISA for quantification of wheat germ agglutinin. J Immunol Methods. 2007; 318:20-9.

124. Ali M, Lillehoj EP, Park Y, Kyo Y, Kim KC. Analysis of the proteome of human airway epithelial secretions. Proteome Sci. 2011;9.

125. Nicholas B, Skipp P, Mould R, Rennard S, Davies DE, O'Connor CD, Djukanovic R. Shotgun proteomic analysis of human-induced sputum. Proteomics. 2006;6:4390-401.

126. Radicioni G, Cao R, Carpenter J, Ford AA, Wang TT, Li Y, Kesimer M. The innate immune properties of airway mucosal surfaces are regulated by 
dynamic interactions between mucins and interacting proteins: the mucin interactome. Mucosal Immunol. 2016;9:1442-54.

127. Kesimer M, Sheehan JK. Mass spectrometric analysis of mucin core proteins. Methods Mol Biol. 2012;842:67-79.

128. Stahl GH, Ellis DB: Biosynthesis of respiratory-tract mucins. A comparison of canine epithelial goblet-cell and submucosal-gland secretions. Biochem J $1973,136: 845-850$

129. Ellis DB, Stahl GH. Biosynthesis of respiratory-tract mucins. Incorporation of radioactive precursors into glycoproteins by canine tracheal explants in vitro. Biochem J. 1973;136:837-44.

130. Rose MC, Lynn WS, Kaufman B. Resolution of the major components of human lung mucosal gel and their capabilities for reaggregation and gel formation. Biochemistry. 1979;18:4030-7.

131. Svartengren K, Wiman $L G$, Thyberg P, Rigler R. Laser light scattering spectroscopy: a new method to measure tracheobronchial mucociliary activity. Thorax. 1989;44:539-47.

132. Sheehan JK, Carlstedt I. Hydrodynamic properties of human cervical-mucus glycoproteins in 6M-guanidinium chloride. Biochem J. 1984;217:93-101.

133. Shah VS, Meyerholz DK, Tang XX, Reznikov L, Abou Alaiwa M, Ernst SE, Karp $\mathrm{PH}$, Wohlford-Lenane $\mathrm{CL}$, Heilmann KP, Leidinger MR, et al. Airway acidification initiates host defense abnormalities in cystic fibrosis mice. Science. 2016;351:503-7.

134. Derichs N, Jin BJ, Song Y, Finkbeiner WE, Verkman AS. Hyperviscous airway periciliary and mucous liquid layers in cystic fibrosis measured by confocal fluorescence photobleaching. FASEB J. 2011;25:2325-32.

135. Birket SE, Chu KK, Liu L, Houser GH, Diephuis BJ, Wilsterman EJ, Dierksen G, Mazur M, Shastry S, Li Y, et al. A functional anatomic defect of the cystic fibrosis airway. Am J Respir Crit Care Med. 2014;190:421-32.

136. Thornton DJ, Davies JR, Kraayenbrink M, Richardson PS, Sheehan JK, Carlstedt I. Mucus glycoproteins from 'normal' human tracheobronchial secretion. Biochem J. 1990;265:179-86.

137. Coles SJ, Reid L. Inhibition of glycoconjugate secretion by colchicine and cytochalasin B. An in vitro study of human airway. Cell Tissue Res. 1981;214:107-18.

138. Carlstedt I, Sheehan JK. Macromolecular properties and polymeric structure of mucus glycoproteins. CIBA Found Symp. 1984;109:157-72.

139. Coles SJ, Bhaskar KR, O'Sullivan DD, Neill KH, Reid LM. Airway mucus: composition and regulation of its secretion by neuropeptides in vitro. CIBA Found Symp. 1984;109:40-60

140. Boat TF, Kleinerman JI. Human respiratory tract secretions. 2. Effect of cholinergic and adrenergic agents on in vitro release of protein and mucous glycoprotein. Chest. 1975;67:32S-4S.

141. Zachara NE, Gooley AA. Identification of glycosylation sites in mucin peptides by edman degradation. Methods Mol Biol. 2000;125:121-8.

142. Thornton DJ, Howard M, Khan N, Sheehan JK. Identification of two glycoforms of the MUC5B mucin in human respiratory mucus - evidence for a cysteinerich sequence repeated within the molecule. J Biol Chem. 1997;272:9561-6.

143. Xia BY, Royall JA, Damera G, Sachdev GP, Cummings RD. Altered Oglycosylation and sulfation of airway mucins associated with cystic fibrosis. Glycobiology. 2005;15:747-75.

144. Jentoft N. Why are proteins O-glycosylated? Trends Biochem Sci. 1990;15:291-4.

145. Sturgess J, Reid L. Secretory activity of the human bronchial mucous glands in vitro. Exp Mol Pathol. 1972;16:362-81.

146. Rose MC, Brown CF, Jacoby JZ, Lynn WS, Kaufman B. Biochemical properties of tracheobronchial mucins from cystic fibrosis and non-cystic fibrosis individuals. Pediatr Res. 1987;22:545-51.

147. Carlstedt I, Sheehan JK. Is the macromolecular architecture of cervical, respiratory and gastric mucins the same? Biochem Soc Trans. 1984;12:615-7.

148. Lai SK, Wang Y-Y, Wirtz D, Hanes J. Micro- and macrorheology of mucus. Adv Drug Deliv Rev. 2009;61:86-100.

149. Vasquez PA, Jin Y, Palmer E, Hill D, Forest MG. Modeling and simulation of mucus flow in human bronchial epithelial cell cultures - part I: idealized axisymmetric swirling flow. PLoS Comput Biol. 2016;12:e1004872.

150. Cheang UK, Roy D, Lee JH, Kim MJ. Fabrication and magnetic control of bacteria-inspired robotic microswimmers. Appl Phys Lett. 2010;97.

151. Ali J, Cheang UK, Martindale JD, Jabbarzadeh M, Fu HC, Kim MJ. Bacteriainspired nanorobots with flagellar polymorphic transformations and bundling. Sci Rep. 2017;7.

\section{Publisher's Note}

Springer Nature remains neutral with regard to jurisdictional claims in published maps and institutional affiliations.

\section{Ready to submit your research? Choose BMC and benefit from:}

- fast, convenient online submission

- thorough peer review by experienced researchers in your field

- rapid publication on acceptance

- support for research data, including large and complex data types

- gold Open Access which fosters wider collaboration and increased citations

- maximum visibility for your research: over $100 \mathrm{M}$ website views per year

At BMC, research is always in progress.

Learn more biomedcentral.com/submissions 